\title{
FORMULASI HUKUM HAK TERKAIT UNTUK PELAKU SENI PERTUNJUKAN TEATER DI YOGYAKARTA
}

Ahmad Muhsin, S.H., M.H.

Contact: ahmadmuhsin77@gmail.com

Diterima: 24 Nov 2020

Direvisi:

Disetujui: 30 Desember 2020

Hak Cipta: (C) 2018

Halaman: 81-101

\begin{abstract}
The main problem in this research is to examine the related rights for actors in theater performances as regulated in Law No. 28 of 2014 concerning copyright, as for the formulations of the problems presented, namely: First, is the formulation of Related Rights in the Copyright Law No. 28 of 2014 in accordance with the views of theater actors in Yogyakarta? Second, How is the formulation of Related Rights in the Copyright Law No. 28 of 2014 according to the future view of theater actors in Yogyakarta? This study uses the normative-empirical method, while the conclusions of this research are: First, that the related rights law rules in the Copyright Law No. 28 of 2014 is complete, Second. The views of theater performers regarding the formulation of rights law related to the future need to be regulated in more detail regarding the standardization of forms of cooperation in the creative process and forming a collective management institution that focuses on protecting theater arts.
\end{abstract}

Keywords: Related Rights, Copyright, Performers, Theater Arts. 


\section{Pendahuluan}

Studi pembahasan tentang perlindungan hak cipta dan hak terkait terhadap seni teater masih sangat jarang dijumpai, dibandingkan dengan pembahasan perlindungan obyek hak cipta dibidang lainnya seperti lagu, musik, buku dan karya tulis. Padahal jika melihat sebuah pertunjukan teater di dalamnya terdapat komponen seni pertunjukan yang sangat beragam, yaitu adanya naskah cerita, gerak aktor, musik pengiring, seni tata panggung, seni tata make up aktor serta seni tata cahaya yang semuanya menjadi satu bagian dalam satu panggung pertunjukan.

Pertunjukan suatu karya seni teater kehadirannya tidak bisa dilepaskan dari sebuah naskah menjadi ruh yang mampu menghidupkan suatu karya seni teater saat divisualkan. Karena dalam sebuah panggung pertunjukan naskah dengan kuatnya mampu memainkan bahasa benda dan tubuh, kehadirannya sangat berpengaruh dalam bangunan suatu pertunjukan (Dahana, 2012). Peran sutradara dalam pemilihan naskah tentunya melalui proses kreatif tersendiri untuk mencocokan naskah mana yang sesuai dengan pertunjukan yang akan digarapnya. Sedangkan unsur utama teater adalah naskah, sutradara, pemain dan penonton. Dalam pertunjukan teater di Indonesia penanggung jawab proses transformasi naskah lakon ke bentuk sebuah pertunjukan adalah sutradara, merupakan pimpinan utama kerja kolektif sebuah pertunjukan teater. (Santosa, dkk, 2018). Sutradara dalam sebuah pertunjukan teater sangat berpengaruh peranannya, baik dan buruknya sebuah pementasan sangat ditentukan oleh peran sutradara. Selain sebagai pimpinan sutradara juga bertanggung jawab terhadap berlangsungnya proses kreatif pertunjukan dan juga terhadap masyarakat atau penonton tentang sebuah pertunjukan yang disajikan.

Seni pertunjukan teater, eksistensinya dilindungi sebagai bentuk suatu ciptaan sebagaimana diatur dalam Undang-Undang Nomor 28 Tahun 2014 Tentang Hak Cipta. Pasal 1 butir 3 UU Hak Cipta menjelaskan bahwa pengertian ciptaan adalah setiap hasil karya cipta di bidang ilmu pengetahuan, seni dan sastra yang dihasilkan atas inspirasi, kemampuan, pikiran, imajinasi, kecekatan, keterampilan, atau keahlian yang di ekspresikan dalam bentuk nyata. Sedangkan berbicara mengenai pertunjukan teater aturan hukum lengkapnya untuk melindungi 
segala unsur yang terkandung didalamnya disebut sebagai hak terkait, Pasal 1 angka 5 Undang-Undang Nomor 28 Tahun 2014 Tentang Hak Cipta menyebutkan bahwa hak terkait adalah hak yang berkaitan dengan hak cipta yang merupakan hak eksklusif bagi pelaku pertunjukan, produser fonogram, atau Lembaga penyiaran.

Dari segi muatan, hak cipta dan hak terkait mengandung esensi monopoli atas Hak Ekonomi atau Economic Rights dan Hak Moral atau Moral Rights. (Soelistyo, 2011). Dilihat dari pengertian tersebut esensi adanya Hak Ekonomi dan Hak moral yang diberikan oleh hak cipta dan hak terkait adalah untuk melindungi kreativitas yang telah diciptakan dalam bentuk asli atau orisinil dari pencipta. Bertujuan untuk menghargai pribadi pencipta yang telah menciptakan karyanya berdasarkan kemampuan kreativitas dan inovasi dengan keahlian yang dimiliki sehingga karya tersebut dapat dilihat, didengar maupun dibaca.

Eksistensi hak cipta dan hak terkait dalam kehidupan tentunya akan menyangkut banyak permasalahan, dalam segi teknologi, industri, sosial dan budaya. Maka melihat dari realita kehidupan tersebut. Wujud perlindungan dari hak cipta dan hak terkait adalah adanya kepastian hukum untuk melindungi segala bentuk ciptaan yang terlahir dari ide kreatif dan inovasi dari setiap manusia. Hukum keberadaannya diharapkan dapat membantu untuk melindungi dan menyelesaikan sengketa ketika terjadi permasalahan dikemudian hari. Melihat keberadaanya hukum bertujuan menjamin adanya kepastian hukum dalam masyarakat dan hukum harus pula bersendikan pada keadilan, yaitu asas-asas keadilan dari masyarakat itu (Kamsil, 1989). Ruang lingkup dalam hak cipta dan hak terkait sangatlah beragam diantaranya adalah naskah teater. dalam proses penciptannya tentu dibutuhkan kreativitas dan inovasi bagi setiap seniman penulis naskah. Sedangkan hak terkait ruang lingkupnya adalah ketika sebuah naskah lakon divisualkan menjadi suatu perlindungan pertunjukan teater.

Kreativitas dan inovasi para seniman yang khususnya berada di Yogyakarta sangat berpengaruh pada hak cipta dan hak terkait. Khususnya bagi seniman pelaku teater yang karyanya sangat berpengaruh dalam dunia kesenian Indonesia. Melihat dalam sebuah pertunjukan teater terdapat karya sastra naskah 
merupakan produk seni yang tergolong dalam ciptaan yang di lindungi oleh Undang-Undang No. 28 Tahun 2014 Tentang Hak Cipta. Naskah teater terciptakan oleh proses kreatif yang terbentuk dari pengalaman kesenian seorang seniman. Menciptakan naskah memang tidak semudah menulis seperti pada umumnya. Segi bahasa atau sastra atau kalimat atau kata atau huruf harus dijadikan tekanan dan acuan utama dalam suatu pementasan sastra berupa naskah.(Noer, 2000). Begitu pula ketika mentransformasikan menjadi suatu pertunjukan, tentunya dalam hal ini memiliki suatu proses kreatif yang wajib dilindungi melalui hak terkait bagi pelaku seni pertunjukan teater.

Penerapan tentang hak terkait dalam pertunjukan teater juga jarang dijamah untuk dikaji lebih lanjut, mengingat dalam tatanan konsep hak terkait aturan yang dibahas juga melindungi hak hukum yang dimiliki oleh pelaku pertunjukan teater. Maka penulis melakukan penelitian dalam aspek "Formulasi Hukum Hak Terkait Untuk Pelaku Seni Teater di Yogyakarta". Apakah subtansi Undang-undang Hak Cipta tentang konsep hak terkait sudah sesuai dengan pandangan para pelaku seni pertunjukan di Yogyakarta.

\section{Rumusan Masalah}

Penelitian ini disusun berdasarkan suatu rumusan masalah sebagai sebagai berikut: Pertama, Apakah formulasi Hak Terkait dalam Undang-Undang Hak Cipta Nomor 28 Tahun 2014 sudah sesuai dengan pandangan pelaku seni Teater di Yogyakarta?; Kedua, Bagaimanakah formulasi Hak Terkait dalam UndangUndang Hak Cipta No. 28 Tahun 2014 menurut pandangan pelaku seni Teater ke depan di Yogyakarta?

\section{Tujuan Penelitian}

Tujuan dilakukannya penelitian ini adalah sebagai berikut: Pertama, Untuk mengkaji dan menganalisa formulasi Hak Terkait dalam UndangUndang Hak Cipta Nomor 28 Tahun 2014 apakah sudah sesuai dengan pandangan pelaku seni Teater di Yogyakarta; Kedua, Untuk mengkaji dan menganalisa formulasi Hak Terkait dalam Undang-Undang Hak Cipta No. 28 Tahun 2014 ke depan sesuai dengan pandangan pelaku seni Teater di Yogyakarta.

\section{Metode Penelitian}

Metode penelitian ini menggunakan tipe penelitian normatifempiris, yaitu dalam penelitiannya penulis melakukan penggabungan 
antara pendekatan hukum normatif dengan adanya penambahan berbagai unsur empiris. Metode penelitian normatif-empiris mengenai implementasi ketentuan hukum normatif yakni dalam hal ini tentang Undang-Undang Nomor 28 Tahun 2014 Tentang Hak Cipta terkhusus tentang konsep hak terkait, yang kemudian dielaborasikan dengan setiap peristiwa hukum tertentu yang terjadi dalam suatu masyarakat khususnya pelaku seni pertunjukan teater.

\section{Hasil Peneilitian Dan Pembahasan}

Formulasi Hak Terkait Dalam UndangUndang No. 28 Tahun 2016 Tentang Hak Cipta

Tujuan dari hak terkait dan hak cipta adalah untuk melindungi kepentingan-kepentingan hukum pada orang tertentu dan badan hukum yang memiliki kontribusi untuk pembuatan karya cipta sehingga tersedia bagi masyarakat atau yang memperoduksi karya cipta terkait lainnya. Hukum dari hak terkait dengan hak cipta bertujuan bahwa produksi sebagai hasil aktivitas orang dan badan hukum tersebut diakui dan dilindungi secara hukum sendirinya, sebagaimana hal tersebut terkait dengan perlindungan kepemilikan karya cipta di bawah hukum hak cipta. Secara tradisional hak terkait diberikan kepada yang menerima manfaat yakni pelaku (performer), produser rekaman suara (producer of phonogram) dan organisasi penyiaran (broadcasting organization). (Jened, 2014).

Pengaturan hukum mengenai hak terkait sebagaimana diatur dalam Undang-Undang No. 28 Tahun 2014 Tentang Hak Cipta, Pasal 1 angka 5 menyatakan: "Hak Terkait adalah hak yang berkaitan dengan hak cipta yang merupakan hak eksklusif bagi pelaku pertunjukan, produser fonogram atau Lembaga Penyiaran.”. Adapun hak yang melekat pada hak terkait, sebagaimana disebut dalam Pasal 3 huruf b UndangUndang No. 28 Tahun 2014 Tentang Hak Cipta, yang dimaksud hak eksklusif pada hak terkait meliputi :

1) Hak moral pelaku pertunjukan;

2) Hak ekonomi pelaku pertunjukan;

3) Hak ekonomi produser fonogram; dan

4) Hak ekonomi Lembaga penyiaran.

Penjelasan lebih lanjut mengenai pengertian dari pelaku pertunjukan, produser fonogram dan Lembaga penyiaran menurut Undang-Undang 
No. 28 Tahun 2014 Tentang Hak Cipta adalah sebagai berikut, pelaku pertunjukan adalah seseorang atau beberapa orang yang secara sendiri-sendiri atau bersamasama menampilkan dan mempertunjukan suatu ciptaan, diatur dalam Pasal 1 angka 6 Undang-Undang No. 28 tahun 2014 Tentang Hak Cipta. Produser fonogram adalah orang atau badan hukum yang pertama kali merekam dan memiliki tanggungjawab untuk melaksanakan perekaman suara atau perekaman bunyi, baik perekaman pertunjukan maupun perekaman suara atau bunyi lainya, diatur dalam Pasal 1 angka 7 Undang-Undang Nomor 28 Tahun 2014 Tentang Hak Cipta. Sedangkan Lembaga penyiaran adalah penyelenggara penyiaran, baik Lembaga publik, Lembaga penyiaran komunitas maupun lembaga penyiaran berlangganan yang melaksanakan tugas, fungsi dan tanggung jawabnya sesuai dengan ketentuan peraturan perundangundangan, diatur dalam Pasal 1 angka 8 Undang-Undang No. 28 Tahun 2014 Tentang Hak Cipta.

Tolak ukur perlindungan hak terkait antara lain mengatur tentang konsep perlindungan hak moral dan hak ekonomi pelaku pertunjukan sebagaimana dijelaskan dalam ketentuan hak eksklusif yang dimiliki oleh hak terkait, menurut Pasal 21 Undang-Undang No. 28 Tahun 2014 Tentang Hak Cipta mengatakan Hak Moral pelaku pertunjukan merupakan hak yang melekat pada pelaku pertunjukan yang tidak dapat dihilangkan atau tidak dapat dihapus dengan alasan apapun walaupun hak ekonominya telah dialihkan. Lebih tegas Pasal 22 Undang-Undang No. 28 Tahun 2014 Tentang Hak Cipta mengatur bahwa hak moral pelaku pertunjukan sebagaimana dimaksud dalam Pasal 21 meliputi hak untuk :

1) Namanya dicantumkan sebagai pelaku pertunjukan, kecuali disetujui sebaliknya; dan

2) Tidak dilakukan distorsi ciptaan, mutilasi ciptaan, modifikasi ciptaan atau hal-hal yang bersifat merugikan kehormatan diri atau reputasinya kecuali disetujui sebaliknya.

Konsepsi perlindungan hak ekonomi pelaku pertunjukan diatur dalam Pasal 23 Undang-Undang No. 28 Tahun 2014 Tentang Hak Cipta, pada intinya hak ekonomi pelaku pertunjukan meliputi hak melaksanakan sendiri, memberikan izin, atau melarang pihak lain untuk 
melakukan :

1) Penyiaran atau komunikasi atas pertunjukan pelaku pertunjukan;

2) Fiksasi dari pertunjukannya yang belum difiksasi;

3) Penggandaan atas fiksasi; pertunjukannya dengan cara atau bentuk apapun;

4) Pendistribusian atas fiksasi pertunjukan atau salinannya;

5) Penyewaan atas fiksasi pertunjukan atau Salinannya kepada publik; dan

6) Penyediaan atas fiksasi pertunjukan yang dapat diakses publik.

Berkaitan dengan masa berlaku hak terkait, sebagaimana aturan hukum mengenai hak cipta juga merumuskan tentang perlindungan jangka waktu ciptaan. Dalam Pasal 62 Undang-Undang No. 28 Tahun 2014 Tentang Hak Cipta menerangkan bahwa masa berlaku hak moral pelaku pertunjukan secara mutatis mutandis tunduk kepada Pasal 57 UndangUndang Nomor 28 Tahun 2014 Tentang Hak Cipta, yang memiliki makna berlaku tanpa batas waktu dan berlaku selama berlangsungnya jangka waktu hak cipta atas ciptaan yang bersangkutan (ketika ciptaan tersebut terjadi distorsi, mutilasi ciptaan, modifikasi ciptaan atau hak yang bersifat merugikan kehormatan diri atau reputasinya si pencipta).

Konsepsi pemberlakuan masa berlaku untuk hak ekonomi pelaku pertunjukan, hak ekonomi produser fonogram, dan hak ekonomi lembaga penyiaran diatur dalam Pasal 63 Undang-Undang No. 28 Tahun 2014 Tentang Hak Cipta, yang perlindungan masa berlaku hak ekonominya dibagi:

1) Pelaku pertunjukan, berlaku selama 50 (lima puluh) tahun sejak pertunjukannya difiksasi dalam fonogram atau audiovisual;

2) Produser fonogram, berlaku selama 50 (lima puluh) tahun sejak fonogramnya difiksasi;

3) Lembaga penyiaran, berlaku selama 20 (dua puluh) tahun sejak karya siaran pertama kali disiarkan; dan

4) Penghitungan masa berlaku perlindungan hak ekonomi sebagaimana dimaksud tersebut diatas terhitung mulai tanggal 1 Januari tahun berikutnya;

Adapun ketentuan-ketentuan aturan hukum pidana yang berkaitan dengan hak terkait sebagaimana disebutkan dalam Undang-Undang Hak Cipta Nomor 28 Tahu 2014 adalah sebagai berikut: 
1) Dipidana dengan pidana denda paling banyak Rp. 100.000.000,00 (serratus juta rupiah) terhadap setiap orang yang mengelola tempat perdagangan dalam segala bentuknya dengan sengaja dan mengetahui membiarkan penjualan dan/atau penggandaan barang hasil pelanggaran hak cipta dan/atau hak terkait ditempat perdagangan yang dikelolanya. Sebagaimana diatur dalam Pasal 114 Undang-Undang Hak Cipta No. 28 Tahun 2014;

2) Dipidana penjara dengan pidana penjara paling lama 1 (satu) tahun sampai dengan paling lama 10 (sepuluh) tahun dan pidana denda paling banyak Rp 100.000.000,00 (serratus juta rupiah) sampai dengan paling banyak denda Rp. 4.000.000.000,00 (empat miliar rupiah) terhadap pelanggaran hak ekonomi pelaku pertunjukan. Hal ini sebagaimana dimaksud dalam Pasal 116 Undang-Undang Hak Cipta No. 28 Tahun 2014;

3) Dipidana penjara dengan pidana penjara paling lama 1 (satu) tahun sampai dengan paling lama 10 (sepuluh) tahun dan pidana denda paling banyak Rp 100.000.000,00 (seratus juta rupiah) sampai dengan paling banyak denda Rp. 4.000.000.000,00 (empat miliar rupiah) terhadap pelanggaran hak ekonomi produser fonogram. Hal ini sebagaimana dimaksud dalam Pasal 117 Undang-Undang Hak Cipta No. 28 Tahun 2014;

4) Dipidana penjara dengan pidana penjara paling lama 4 (empat) tahun sampai dengan paling lama 10 (sepuluh) tahun dan pidana denda paling banyak Rp 1000.000.000,00 (satu miliar rupiah) sampai dengan paling banyak denda Rp. 4.000.000.000,00 (empat miliar rupiah) terhadap pelanggaran hak ekonomi lembaga penyiaran sebagaimana dimaksud dalam Pasal 118 Undang-Undang hak Cipta No. 28 Tahun 2014.

\section{Hak Terkait Pertunjukan Teater}

Menurut ketentuan Pasal 3 Rome Convention, yang tercakup dalam pengertian pelakon (performer) adalah para aktor, penyanyi, musisi, penari dan orang lain yang dalam sabuah tampilan lagu, penyampaian berita, pembaca deklamasi (sajak), pelakon dalam permainan sandiwara atau drama, atau orang yang tampil dalam kegiatan seni dan sastra, mereka inilah 
yang secara hukum didudukan sebagai subjek hukum hak atas neighboring rights. Disamping para pelaku produser rekaman suata dan lembaga penyiaran. (Saidin, 2013).

Pertunjukan teater pemegang hak terkait pelaku pertunjukan tersebut menurut hemat penulis jatuh kepada Aktor, Penata panggung (stage manager), Penata cahaya lampu (lighting), Penata musik, Penata suara, Penata rias (make up) dan penata busana, adapun peran mereka dalam pertunjukan teater sehingga secara hukum mendapat perlindungan hak terkait, adalah sebagai berikut, (Santosa, 2008):

1) Aktor adalah pihak yang memerankan dan mampu menghidupkan tokoh dalam naskah lakon menjadi sosok yang nyata. aktor adalah alat untuk memeragakan tokoh. tetapi bukan sekedar alat yang harus tunduk kepada naskah. Aktor mempunyai wewenang membuat refleksi dari naskah melalui dirinya. Agar bisa merefleksikan tokoh menjadi sesuatu yang hidup, pemain dituntut menguasai aspek-aspek pemeranan yang dilatihkan secara khusus, yaitu jasmani (tubuh/fisik), rohani (jiwa/emosi), dan intelektual.
2) Penata Panggung (Stage Manager) adalah pihak yang melakukan pengaturan pemandangan di panggung selama pementasan berlangsung. Tujuannya tidak sekedar supaya permainan bisa dilihat penonton tetapi juga menghidupkan pemeranan dan suasana panggung.

3) Penata cahaya lampu (lighting) adalah pihak yang melakukan pengaturan pencahayaan di daerah sekitar panggung yang fungsinya untuk menghidupkan permainan dan dan suasana lakon yang dibawakan, sehingga menimbulkan suasana istimewa.

4) Penata musik adalah pihak yang melakukan pengaturan musik yang mengiringi pementasan teater yang berguna untuk memberi penekanan pada suasana permainan dan mengiringi pergantian babak dan adegan.

5) Penata suara adalah pihak yang melakukan pengaturan keluaran suara yang dihasilkan dari berbagai macam sumber bunyi seperti; suara aktor, efek suasana, dan musik. Tata suara diperlukan untuk menghasilkan harmoni. 
6) Penata rias (Make Up) dan penata busana adalah pihak yang melakukan pengaturan rias dan busana yang dikenakan pemain. Gunanya untuk menonjolkan watak peran yang dimainkan, dan bentuk fisik pemain bisa terlihat jelas penonton.

Pandangan Pelaku Seni Teater Di Yogyakarta Tentang Formulasi Hukum Hak Terkait Dalam Undang-Undang Nomor 28 Tahun 2014 Tentang Hak Cipta

Setelah penjelasan lebih lanjut mengenai aturan hukum hak terkait sebagaimana diatur dalam UndangUndang Hak Cipta No. 28 Tahun 2014 dalam ruang lingkut pertunjukan teater, yang esensinya menjelaskan mengenai objek hak terkait pertunjukan teater, perlindungan hak terkait pelaku pertunjukan teater dan pemanfaatan hak terkait pertunjukan teater khususnya bagi para pelaku pertunjukan teater di Yogyakarta. Selanjutnya penulis menyajikan hasil wawancaranya dengan para pelaku pertunjukan teater di Yogyakarta yang notabene mereka dalam dunia teater berlatar belakang sebagai praktisi aktor, dan akademisi teater, pertanyaan yang dilontarkan oleh penulis, yaitu tentang apakah aturan hukum hak terkait sebagaimana penulis jelaskan tersebut diatas sudah lengkap pengaturan hukumnya menurut para pelaku pertunjukan teater di Yogyakarta, adapun hasil data yang penulis peroleh berdasarkan metode wawancara sebagai berikut.

Rukman Rosardi. S.Sn., M.Sn., Dosen Fakultas Seni Pertunjukan ISI Yogyakarta dan aktif mengajar kelas acting di Komunitas Salihara Jakarta, dalam wawancaranya dengan penulis memberikan pandangnya tentang penerapan hak terkait sebagaimana diatur dalam Undang-Undang Hak Cipta No. 28 Tahun 2014 untuk pelaku seni pertunjukan teater di Yogyakarta pada khususnya, menurut pendapat beliau adalah sebagai berikut: (Rosardi, 22 Juli 2020, Personal Interview).

"Bahwa jika berbicara mengenai pandangan saya tentang aturan hukum hak terkait sebagaimana diatur dalam Undang-Undang No. 28 Tahun 2014 Tentang Hak Cipta, menurut saya saturannya sudah lengkap, contohnya diatur tentang penghargaan hak moral pelaku pertunjukan dalam seni teater Memang benar sudah sesuai dan sudah diterapkan, dengan contoh penghargaan kepada aktor dan pihak lainnya yang terlibat dalam pertunjukan teater selalu 
dipublikasikan nama-nama tersebut, salah satunya contohnya ketika saya mendapatkan suatu project dengan Komunitas Salihara, disana nama aktor dan tim artistik lainya disebutkan pada media-media promosi pertunjukan. Selanjutnya seperti halnya ketika saya mengajar dikelas seni pertunjukan teater, saya selalu menyarankan kepada mahasiswa saya, untuk meminta izin terlebih dahulu kepada mereka yang menciptakan, ketika dia (mahasiswa) saya akan melakukan tugas kesenian mementaskan karya cipta orang lain tersebut sebagai tugas keseniannya tersebut, hal ini sebagai sarana penghargaan kepada pihak yang telah menciptakan suatu pertunjukan tersebut sebagaimana aturan yang dijelaskan tadi mengenai penghargaan hak moral pelaku pertunjukan tentang suatu ciptaanya selanjutnya tentang penerapan hak ekonomi pelaku pertunjukan salah satu kelompok teater yang menerapkan pada saat sekarang yaitu di lembaga teater yang besar seperti Komunnitas Salihara, pengalam saya berproses kreatif disana sudah menerapkan sistematik mengenai aturan hukum menghargai karya dan menghargai pelaku seni yang terlibat dalam suatu pertunjukan teater, yang terlibat dalam proses kreatif yang dibuat oleh Komunitas Salihara. Namun bentuk konsensus hukum yang diberlakukan sepengalaman saya tentang hak ekonomi pelaku pertunjukan yaitu bentuk pemanfaatanya berupa hukum perjanjian kontrak proses kreatifnya adalah kontrak putus dalam pertunjukan, dan hak hasil pertunjukan akan diambil oleh Komunitas Salihara sehingga selanjutnya hak tersebut diserahkan kepada Komunitas Salihara untuk menggunakan hasil visual tersebut. Sedangkan proses sengketa hukum tentang teater sejauh pengalaman saya belum pernah terjadi”. Pandangan selanjutnya tentang penerapan hak terkait sebagaimana diatur dalam Undang-Undang No. 28 Tahun 2014 Tentang Hak Cipta khususnya bagi pertunjukan seni teater juga dikemukakan oleh Dr. Koes Yuliadi. M. Hum., Dosen Seni Pertunjukan Teater di Fakultas Seni Pertunjukan ISI Yogyakarta, dalam pengalaman dan pandangan pribadinya beliau mengatakan, (Yuliadi, 28 Juli 2020, Personal Interview):

"Bahwa dalam perkembangan teater modern di Indonesia dan di Yogyakarta pada khususnya sudah mulai muncul etika-etika yang harus dan sudah disadari, seperti halnya meminta izin ke 
pencipta pertunjukan teater sebelumnya, ketika akan melakukan mementaskan karyanya, itu sudah mulai berjalan, dan terkait penerapan hak moral kepada pelaku pertunjukan pun sudah berjalan dengan lama, seperti halnya pencantuman nama para aktor dan tim artistik dalam proses kreatif suatu pertunjukan. Selanjutnya juga beberapa kelompok teater yang sudah mapan seperti halnya Teater Gandrik, sudah menerapkan kontrak kerja antara aktor, tim artistik, tim musik, dan pendukung lainya dengan pimpinan produksi, selanjutnya dalam hal hak moral perlaku pertunjukan untuk menjaga ciptaanya, ketika orang lain membawakan karya mereka, hal yang sering terjadi menyantumkan nama di pencipta pertunjukan teater tersebut, dan etika selanjutnya adalah mengkomunikasikan dengan mereka, walaupun ada teori adaptasi naskah dalam hukum pertunjukan teater yang dalam penerapannya bisa juga melalui konsep terilhami, menerjemahkan, menyadur dan mengadaptasi. Dan hal ini memang sudah menjadi kewajaran dalam teater, dan yang menjadi kontroversial banget dalam teori tersebut suatu pertunjukan teater yang bagus adalah yang berbeda dengan pertunjukan yang utama. Jadi selama dalam bentuk gagasan hal tersebut memang dibolehkan. Selanjutnya mengenai hak ekonomi pelaku pertunjukan khususnya di seni teater, kita perlu melihat untuk saat ini industri teater di Indonesia belum terbangun secara aktif sebagaimana seni musik dan lagu, sehingga praktek menghargai suatu seniman teater penghargaan terhadap aktor yang dibangun adalah persetujuan individual yang dimuat dalam kontrak putus, mengingat kembali lagi ke konsep awal bahwa industri teater di Indonesia belum terbangun secara mapan guna menghasilkan nilai ekonomi kepada para pelaku teater sendiri. Namun pemanfaatan hak terkait pada pertunjukan teater perjanjian yang digunakan yaitu kontrak-putus yang diberlakukan baik melalui lisan maupun kontrak hitam diatas putih, namun lebih mengarah ke hal penghargaan secara sosial dengan langsung membayar para honor kepada aktor dengan melihat track record actor tersebut dalam dunia kesenian yang sudah dijalankan. Namun bagi saya sebenernya konsep hukum sebagaimana dijelaskan soal terkait bagi pelaku pertunjukan ini sangat bagus ya, dan bagi saya bisa menjadi bekal pengetahuan bagi para pelaku seni pertunjukan teater tentang adanya 
konsensus hukum yang mengatur hak ekonominya dan pemanfaatannya".

Drs. Agus Prasetiya. M.Sn. Dosen Seni Pertunjukan Teater di Fakultas Seni Pertunjukan ISI Yogyakarta, juga mengemukakan pandangan perihal penerapan hak terkait sebagaimana diatur dalam Undang-Undang No. 28 Tahun 2014 Tentang Hak Cipta bagi pelaku pertunjukan, dalam wawancaranya dengan penulis point yang beliau sampaikan adalah sebagai berikut, (Prasetiya, 28 Juli 2020, Personal Interview):

"Bahwa penghargaan hak terkait pelaku pertunjukan kepada aktor ataupun jajaran tim artistik ketika melakukan suatu pertunjukan teater memang diterapkan, contoh yaitu nama-nama tersebut disebutkan dalam karya petunjukan teater, dengan beragam media. Sehingga sebagaimana yang dijelaskan tadi, saya kira aturan penghargaan tentang hak moral pelaku pertunjukan teater pada intinya sudah sesuai, apalagi ketika yang melakukan produksi pertunjukan adalah teater besar seperti Teater Koma, Teater Gandrik atau kelompok kesenian teater tradisi ketoprak di Yogyakarta. Terkait etika nama aktor atau tim pendukung yang biasanya dikenal dengan tim artistik dalam pertunjukan teater memang benar namanama tersebut dicantumkan, dan terkait ketika ada orang mau membawakan ulang pertunjukan teater tersebut pun, kehadiran sekarang etikanya sudah mulai terbangun dikalangan seniman teater, walaupun belum semuanya. Dan proses penerapan hak ekonomi pelaku pertunjukan sebagaimana pengalaman saya dalam dunia teater yaitu penghargaan hak ekonomi yang diberikan kepada pelaku pertunjukan ketika melakukan proses kreatif pertunjukan oleh salah satu kelompok teater misalnya Teater Gandrik yang sepengalaman saya yaitu ada aturan tersendiri berdasarkan job yang dia mainkan, misalnya fee untuk aktor, sutradara, penulis naskah, pimpinan produksi dan ditambah fee untuk absensi latihan yang dihitung perhari. Namun konsep yang diterapkan juga perjanjian putus, artinya segala hak hari pementasan tersebut hasilnya dikelola oleh Teater Gandrik, sebagai wujud pemanfaatan hak terkait dalam pertunjukan teater ya".

Uraian dari semua pandangan pelaku seni teater tentang formulasi hukum hak terkait sebagaimana diatur dalam Undang-Undang No. 28 Tahun 2014 Tentang Hak Cipta bagi pelaku pertunjukan telah diutarakan sebagaimana penulis menjelaskannya 
berdasarkan metode wawancara tersebut diatas. Sehingga berdasarkan data wawancara tersebut diatas penerapan hak terkait bagi pelaku pertunjukan teater esensinya dalam tataran formulasi hukum yang berlaku sekarang yaitu UndangUndang No. 28 Tahun 2014 Tentang Hak Cipta menurut para pelaku pertunjukan seni teater di Yogyakarta dapat dikatakan sudah lengkap.

Argumentasi hukum secara normatif menyatakan bahwa UndangUndang No. 28 Tahun 2014 Tentang Hak Cipta sudah lengkap, mengingat hukum sebagai suatu norma mempunyai ciri kekhususan, yaitu hendak melindungi, mengatur serta memberikan kesimbangan dalam menjaga kepentingan umum. (Ashibily, 2016). Dalam hal ini yaitu melindungi kepentingan pelaku seni pertunjukan teater. Penjelasan selanjutnya dalam berargumentasi bahwa UndangUndang No. 28 Tahun 2014 Tentang Hak Cipta dikatakan sudah lengkap dalam melindungi hak terkait pelaku seni pertunjukan yaitu mengingat memuat perlindungan hukum yang cukup melindungi hak yang dimiliki oleh para pelaku pertunjukan.

Argumentasi hukum selanjutnya dalam melihat Undang-Undang No. 28 Tahun 2014 Tentang Hak Cipta, Budi Agus
Riswandi memandang didalam UndangUndang No. 28 Tahun 2014 Tentang Hak Cipta penormaan yang mengarah kepada kepentingan pencipta/pemegang hak cipta/hak terkait lebih diperjelas, diperluas serta diuraian secara terperinci. Hal ini semisal dapat dilihat pada ketentuan Pasal 3 Undang-Undang No. 28 Tahun 2014 Tentang Hak Cipta yang mengatur tentang 2 (dua) hak, yakni : hak cipta dan hak terkait. Sedangkan yang mentaur lebih khusus tentang hak terkait lebih rinci lagi diatur dalam ketentuan Pasal 20 sampai Pasal 30 Undang-Undang No. 28 Tahun 2014 Tentang Hak Cipta. (Riswandi, 2016). Hal ini menandakan bahwa dalam hal ini sudah diatur dengan terperinci perihal aturan hukum hak terkait sebagaimana diatur dalam UndangUndang No. 28 Tahun 2014 Tentang Hak Cipta, sehingga dapat dikatakan aturan tersebut sudah lengkap.

Berdasarkan uraian argumentasi hukum secara normatif, dielaborasikan dengan pandangan para pelaku seni pertunjukan teater memandang tentang aturan hukum hak terkait sebagaimana diatur dalam Undang-Undang No. 28 Tahun 2014 Tentang Hak Cipta, esensinya adalah dalam objek hak 
terkait menyangkut tentang hak moral dan hak ekonomi pelaku pertunjukan teater, dalam perlindungan hak terkait mengatur tentang perlindungan hukum terhadap perbuatan pidana apabila hak para pelaku pertunjukan teater dilanggar dan dalam pemanfaatanya mengatur tentang konsep perjanjian lisensi, pengaturan royalti dan gugatan atas hak yang dilarang pada pelaku seni pertunjukan teater dalam ruang lingkup hukum perdata, maka dalam hal ini dapat dikatakan bahwa aturan hukum hak terkait sebagaimana diatur dalam Undang-Undang No. 28 Tahun 2014 Tentang Hak Cipta sudah lengkap.

\section{Pandangan Pelaku Seni Teater Di Yogyakarta Tentang Formulasi Hak Terkait Undang-Undang Nomor 28 Tahun 2014 Tentang Hak Cipta Ke Depan}

Perjalanan Undang-Undang No. 28 Tahun 2014 Tentang Hak Cipta sudah berjalan sekita 6 (enam) tahun diterapkan di negara ini. Tentu saja para pelaku seni teater juga mempunyai pandangan ke depan terkait penerapan hukum hak cipta dan hak keterkait guna kepentingan hukum mereka, baik itu dari tataran norma aturan hukum melalui UndangUndang, maupun bentuk implementasinya yang harus dibenahi. Mengamini istilah yang disampaikan oleh Soedikno Mertokusumo bahwa berdasarkan kriterium waktu berlakunya sebuah aturan hukum dibagi menjadi 2 (dua), yaitu pertama Ius Constitutum artinya yaitu hukum yang berlaku di masa sekarang, dan kedua Ius Constituendum yaitu hukum yang dicita-citakan (masa mendatang). (Mertokusumo, 2006). Berbicara mengenai formulasi hukum ke depan tentang hak terkait untuk pelaku seni pertunjukan teater berarti dalam hal ini berbicara mengenai hukum yang dicita-citakan (Ius Constituendum).

Untuk selanjutnya berdasarkan kesulitan-kesulitan tentang implementasi penerapan hak terkait sebagaimana diatur dalam UndangUndang Nomor 28 Tahun 2014 Tentang Hak Cipta, para pandangan para pelaku seni pertunjukan, mengemukkan pandangannya mengenai formulasi hukum hak terkait ke depan, sebagaimana data yang penulis peroleh melalui wawancara dengan berbagai narasumber antara lain hal-hal yang dikemukakan sebagai berikut. Rukman Rosardi. S.Sn. M.Sn., berpendapat untuk mewujudkan hak terkait untuk perlaku pertunjukan teater sebagaimana diatur dalam Undang-Undang No. 28 Tahun 
2014 Tentang Hak Cipta, formulasi bersama yang harus disiapkan guna implementasi hukumnya sesuai dengan aturan hukum yang berlaku menurut pandangan beliau adalah sebagai berikut: (Rosardi, 22 Juli 2020, Personal Interview)

\section{a. Meningkatkan}

spirit

profesinoalisme, profesionalisme dalam hal ini diartikan bahwa setiap aktor dan para pelaku seni teater guna menciptakan formulasi hak terkait untuk seni pertunjukan teater, para pelakunya harus meningkatkan kualitas baik itu untuk individu seniman dan/atau kelompok teater itu sendiri, sebagai contoh dalam praktek latihan teater misal soal waktu latihan sikap profesional menghargai kedisiplinan waktu dalam proses kreatif teater hanya beberapa orang yang menerapkan, misalnya dari 10 pemain atau aktor hanya sekira 3 orang yang profesional masalah dengan waktu latihan, selanjutnya masalah kehafalan naskah pun dalam arti professional masih hanya sebagian aktor yang menerapkan ketika disuruh menghafal naskah dan diberikan waktu. Hal ini berbeda dengan management film, jika tidak hafal mati lah siaktor mengingat film tersebut tidak bisa ditake, dan sikap itu semua belum sepenuh diterapkan. Faktorfaktor sederhana tersebutlah yang harus ditanamkan dalam tubuh seniman secara pribadi maupun kelompok teater, guna menunjukan bahwa seniman teater juga memiliki nilai profesionalitas yang tinggi.

b. Menciptakan

manajemen pertunjukan profesional, formulasi ini sangat penting mengingat ketika suatu manajemen pertunjukan diciptakan secara profesional akan menimbulkan tujuan para seniman teater untuk memperoleh kehidupan yang lebih bagus, tata cara proses kreatif pertunjukan lebih tertata dan kepastian-kepastian hak yang dimiliki oleh seniman teater terjamin, walaupun untuk saat ini di Indonesia belum ada yang menerapkan dengan sempurna. Sehingga image yang terbangun teater hanya sebagatas menghadirkan romantisme, mengingat senimannya sama-sama suka memproduksi suatu teater.

c. Membangun relasi dengan pihakpihak terkait, seniman teater baik individu maupun kelompok, harus mempunyai relasi supaya 
mendapatkan dukungan dari lembagalembaga, ruang-ruang serta mediamedia yang mensupprot mereka untuk dapat menjadikan teater sebagai profesi yang professional jika tidak ya gak bakalan terjadi. Makanya sama halnya tadi banding dengan kelompok teater yang berada di Broadway Amerika Serikat, kelompok teater anti mainstream di Amerika Serikat non Broadway kehidupan ekonomi mereka pun masih belum stabil. Tapi kalo kelompok teater Broadway baru dapat dikatakan mereka bisa menghidupi kelompok teaternya.

Formulasi pandangan kedepan selanjutnya perihal menerapkan hak terkait untuk pertunjukan seni teater juga dikemukakan oleh Dr. Koes Yuliadi. M.Hum, sebagaimana aturan hak terkait tersebut diatur dalam Undang-Undang No. 28 Tahun 2014 Tentang Hak Cipta, melalui wawancaranya dengan penulis, beliau menyampaikan pandangan-pandangannya sebagai berikut, (Yuliadi, 28 Juli 2020, Personal Interview):

\section{a. Edukasi Hukum Kepada Seniman}

Teater, pandangan beliau mengatakan bahwa untuk sekarang sosialisasi perihal hak cipta dan hak terkait untuk pelaku seni teater memang sangatlah kurang, dan ini menjadi suatu pekerjaan bersama guna mewujudkan seniman yang melek hukum, mengingat dalam tataran praktek pola ideologi yang terbangun dalam kalangan pelaku seni teater kurang memperdulikan terkait hasil karya mereka memiliki nilai ekonomis atau tidak, sedangkan pada faktanya aturan hukum negara melalui UndangUndang Hak Cipta No. 28 Tahun 2014 sudah mengakomodir hak dan kewajiban para pelaku seni teater khususnya, sehingga edukasi ini menurut saya sangat diperlukan.

b. Bekerjasama dengan media profesional, berbicara mengenai era digital sekarang ini ruang kesenian teater memang harus mengenal tentang media perekaman yang profesional, sehingga dalam goal yang didapatkan dari seni pertunjukan khususnya teater tidak hanya mendapatkan kebahagian yang nilainya psikologis, hal ini memang berbeda dengan kesenian teater yang sudah diterapkan dalam dunia barat, penerapan yang terjadi teater sudah menjadi suatu komoditas industri pertunjukan, yang didalamnya memiliki assosiasi, 
lembaga managerial sehingga dalam hal ini sisi profesionalisme sudah terbangun dengan sendirinya dan memiliki daya tawar.

c. Peran serta dan dukungan Government, mengingat teater juga merupakan pola kesenian yang berbentuk kebudayaan sehingga penerapan hak bagi pelaku seni pertunjukan, produser rekaman dan lembaga penyiaran dalam ruang kesenian teater memang sangat berat, dibutuhkan peran extra dari pemerintah, beserta lembaga dan penegak hukum terkait yang turut serta mengawalnya, ditambah dengan edukasi hukum yang harus ditanamkan kepada pelaku seni pertunjukan teater.

\section{d. Membentuk lembaga manajemen}

kolektif, berbeda dengan pola kesenian yang sudah ada dan diterapkan oleh kalangan seniman musik, dalam dunia teater diperlukan pengelolaan manajemen kolektif dalam karya seni teater, sehingga kemungkinan jika dikelola dengan bijak bisa diterapkan industri teater. Dan saya pun memiliki keyakinan dalam dunia teater dalam mengelola karyanya sehingga mendatangkan intensif bagi para pelaku pertunjukan tentunya hal ini harus adanya peran serta dari lembaga dan pelaku diluar pelaku pertunjukan teater itu sendiri. Mengingat kehadiran lembaga kolektif yang mengelola suatu pertunjukan teater juga dapat menentukan kualitas suatu pertunjukan tersebut, tapi terkait waktunya yang jelas butuh waktu panjang namun jika ada kemauan pasti bisa dijalankan konsep penghargaan hak terkait guna pelaku seni pertunjukan teater, produser rekaman dan lembaga penyiaran.

Pendapat lainya tentang formulasi hukum ke depan dalam hal penerapan hak terkait untuk pelaku seni pertunjukan teater sebagaimana diatur dalam Undang-Undang No. 28 Tahun 2014 Tentang Hak Cipta, juga diwacanakan oleh Drs. Agus Prasetiya. M.Sn, dalam wawancaranya dengan penulis beliau menjabarkan perihal pandangan formulasi tentang hak moral pelaku pertunjukan dan hak ekonomi pelaku pertunjukan kedepan sebagai berikut, (Prasetiya, 28 Juli 2020, Personal Interview):

"Bahwa pandangan kedepan sebetulnya bisa para pelaku seni pertunjukan teater, dan pihak yang memegang hak 
terkait mendapatkan dalam dunia teater khususnya mendapatkan ruang Industri seperti halnya industri Musik, adapun tolak ukurnya yang utamanya harapannya para pelaku seni pertunjukan teater dapat mengedisiplinkan etika dan moral dalam berporses kreatif, selain itu pemerintah juga dapat menerapkan moral etika kepada para seniman. Selain itu sosialisasi terkait aturan hukum hak cipta dan hak terkait juga harus diterapkan dalam tataran para pelaku seni teater, sebagai contoh kerjasama dengan para gedung pertunjukan untuk memberikan informasi kepada para pelaku seni teater, dalam melakukan suatu pertunjukan teater juga harus memperhatikan pola visual yang bagus, unsur-unsur yang terlibat juga memiliki nilai professional dalam unsur pendukung teater. Sehingga hasil yang dihasilkan adalah pertunjukan yang professional dan layak untuk dipertunjukan dalam suatu pertunjukan teater. Selain itu juga didukung oleh peran serta lembaga dan pemerintah harus saling bersinegri untuk sama-sama dapat menerapkan aturan hukum hak cipta dan hak terkait".

Sejauh penelusuran informasi yang penulis lakukan dalam kajian tesis ini, faktor-faktor sebagaimana tersebutlah di atas merupakan pandangan para pelaku seni teater tentang harapan mereka dalam pembentukan formulasi hukum hak terkait ke depan. Bahwa esensi dari hak terkait sebagaimana diatur dalam Undang-Undang No. 28 Tahun 2014 Tentang Hak Cipta untuk pelaku pertunjukan teater sudah sesuai dengan pandangan pelaku seni teater di Yogyakarta pada khususnya, namun masih ada aturan hukum yang dicitacitakan guna memperoleh kepastian hukum bagi pelaku seni pertunjukan teater. Namun kajian penulis berdasarkan data wawancara yang telah dikaji, bentuk formulasi hukum tersebut berupa perbaikan implementasi hukum hak terkait sebagaimana diatur dalam Undang-Undang No. 28 Tahun 2014 Tentang Hak Cipta, Adapun formulasi hak terkait untuk pelaku seni teater di Yogyakarta kedepan yang penulis dapat sajikan yaitu pengaturan tentang standarisasi kerjasama dan pembentukan lembaga managemen kolektif.

\section{Penutup}

Uraian dari penutup penelitian ini menghasikan kesimpulan sebagai berikut : Pertama, Formulasi hukum hak terkait dalam Undang-Undang No. 28 Tahun 2014 Tentang Hak Cipta esensinya sudah lengkap, mengingat 
penormaan yang mengarah kepada kepentingan pencipta/ pemegang hak cipta/ hak terkait lebih diperjelas, diperluas serta diuraian secara terperinci. Sedangkan yang mengatur lebih khusus tentang hak terkait lebih rinci lagi diatur dalam ketentuan Pasal 20 sampai Pasal 30 Undang-Undang No. 28 Tahun 2014 Tentang Hak Cipta. Bahwa argumentasi hukum selanjutnya pemanfaatan hak terkait pertunjukan teater juga telah diatur dengan jelas sebagaimana konsep perjanjian lisensi diatur dalam Pasal 80 sampai dengan Pasal 83 Undang-Undang No. 28 Tahun 2014 Tentang Hak Cipta, penjelasan mengenai royalti diatur dalam Pasal 1 angka 21 Undang-Undang Nomor 28 Tahun 2014 Tentang Hak Cipta, pengaturan mengenai Lembaga Manajemen Kolektif diatur dalam Pasal 92 dan Pasal 93 Undang-Undang No. 28 Tahun 2014 Tentang Hak Cipta, dan diatur pula mengenai upaya hukum gugatan keperdataan di Pengadian Niaga. Sehingga aturan hukum normatif diperoleh kesimpulan aturan Undang-Undang No. 28 Tahun 2014 Tentang Hak Cipta yang mengatur tentang hak terkait perlaku pertunjukan dapat dikatakan sudah lengkap. Kedua, Pandangan pelaku seni pertunjukan teater di Yogyakarta ke depan tentang formulasi hukum hak terkait untuk seni pertunjukan teater adalah mengingat Undang-Undang No. 28 Tahun 2014 Tentang Hak Cipta adalah dalam tataran praktek implementasi aturan hukum tersebut masih terhadap kesulitan-kesulitan yang dialami oleh para pelaku seni pertunjukan di Yogyakarta, antara lain yaitu : belum adanya aturan hukum yang baku mengatur tentang bentuk standarisasi kerjasama pelaku seni pertunjukan teater, dan belum terbentuknya Lembaga Manajemen Kolektif di bidang seni pertunjukan teater. Sehingga berdasarkan kesulitan-kesulitan yang dialami oleh pelaku seni pertunjukan teater di Yogyakarta tersebut diatas, bentuk formulasi implementasi aturan hukum kedepan tentang aturan hukum yang mengatur standarisasi bentuk kerjasama para pelaku seni pertunjukan teater dalam berporses kreatif, dan membentuk Lembaga Manajemen Kolektif Nirlaba dibidang seni pertunjukan teater yang esensinya dapat melindungi hak ekonomi yang dimiliki oleh pencipta dan pemegang hak terkait untuk pelaku seni teater dalam hal pemanfaatan hak terkait pertunjukan teater. Sehingga dalam hal ini kedepannya industri teater akan terbentuk, dan para pelaku seni 
pertunjukan teater dapat meningkatkan profesionalisme dalam berporses kreatif untuk menghasilkan suatu produk pertunjukan teater di Yogyakarta.

\section{Daftar Pustaka}

Buku

Ashibily. (2016). Hukum Hak Cipta Tinjauan Khusus Performing Rights Lagu Indie Berbasis Nilai Keadilan. Yogyakarta: Genta Publishing.

Santosa, Eko, Dkk. (2008). Seni Teater Jilid

1. Jakarta: Direktorat Pembinaan Sekolah Menengah Kejuruan

Direktorat Jenderan Manajeman

Pendidikan Dasar Dan Menengah

Departemen Pendidikan Nasional.

Panca Dahana, Radhar. (2012). Teater

Dalam Tiga Dunia. Jakarta.

Kementerian Pendidikan Dan

Kebudayaan Direktorat Jendral

Kebudayaan.

Jened, Rahmi. (2014). Hukum Hak Cipta

(Copyright's Law). Bandung: Citra Aditya Bakti.

Kansil, C.S.T. (1989). Pengantar Ilmu

Hukum Dan Tata Hukum Indonesia.

Jakarta. Balai Pustaka. (P. 40-41).

Noer, Arifin C, Dkk. (2000). Yudiaryani.

Ideologi Teater Modern Kita.

Yogyakarta: Pustaka Gondho Suli.

Mertokusumo. Sudikno. (2006). Penemuan
Hukum Sebuah Pengantar.

Yogyakarta: Liberty.

Riswandi. Budi Agus. (2016). Doktrin Perlindungan Hak Cipta Di Era Digital. Yogyakarta: Fh Uii Press.

Saidin. Ok..(2013). Aspek Hukum Hak Kekayaan Intelektual (Intellectual Property Rights). Jakarta: Rajawali Press.

Soelistyo, Hendry. (2011). Hak Ciptatanpa Moral. Jakarta: Rajawali Pres.

\section{Undang-Undang}

Undang-Undang Nomor 28 Tahun 2014

Tentang Hak Cipta

\section{Wawancara}

Rosardi, Rukman. (22 Juli 2020).

Personal Interview.

Yuliadi, Koes. (28 Juli 2020). Personal Interview.

Prasetiya, Agus. (28 Juli 2020). Personal Interview. 